\title{
DESIGN OF MSMES DEVELOPMENT THROUGH PROFIT SHARING SCHEMES
}

\author{
Taudlikhul Afkar $^{1 *}$, Teguh Purwanto ${ }^{1}$, Fauziyah $^{1}$, Ferry Hariawan $^{1}$, Siti Istikhoroh ${ }^{1}$ \\ ${ }^{1}$ Universitas PGRI Adi Buana Surabaya, Indonesia \\ ”e-mail: afkar@unipasby.ac.id
}

\begin{abstract}
The purpose of this study is to find the design of Micro, Small, and Medium Enterprises (MSMEs) development through profit-sharing schemes seen from the perspective of MSMEs actors in East Java Indonesia. This research was conducted in East Java, Indonesia, selecting research locations carried out randomly and then determining the respondents proportionally. Respondents in this study were 220 MSMEs actors using the proportional random sampling technique. The data analysis technique used is warped partial least square to look for the design partially and through intervening. This study uses mudarabah financing and musharakah financing as exogenous variables, principles of profit-sharing distribution as intervening variables, and development of MSMEs as endogenous variables. The findings in this study are the contribution of profit-sharing distribution as an intervening variable in the development of MSMEs through the mudarabah financing scheme and the musharakah financing with the dominance of the musharakah financing. The ideal design of the development of MSMEs is the use of mudarabah financing and musharakah financing by applying the profit-sharing distribution principle following the principles of Islamic Sharia.
\end{abstract}

Keywords: MSMEs; Mudarabah; Musharakah; Profit Sharing; Islamic Financial Institutions

This is an open access article under the CC BY-SA license.

Copyright (c) 2021 by Author. Published by Universitas Pendidikan Ganesha.

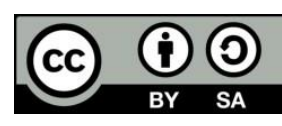

\section{INTRODUCTION}

Micro, small, and medium enterprises (MSMEs) are currently experiencing ups and downs with the development of technology in the industrial era 4.0 where currently many are using online and transaction media with the occur covid-19 pandemic. Micro businesses are currently still a concern in their development to become one of the components that increase economic growth (Pakpahan, 2020). Including in the area of East Java which has 6.553.694 micro businesses, 261.827 small businesses, and 30.410 medium enterprises that are dominant in the nonagricultural sector. According to the Central Statistics Agency, the contribution of MSMEs until 2020 was $57.25 \%$ to the East Java economy with the most dominant distribution of added value in the processing industry at $28.86 \%$. It is different from MSMEs in Central Java which have a contribution to the economy of $50 \%$. Meanwhile, the contribution of MSMEs in West Java is $60 \%$. The size of each contribution shows that MSMEs are able to support regional and national economies, therefore it is necessary to develop significant MSMEs so that they can increase people's purchasing power, of course with the role of government institutions and financial institutions in providing financing as stated in the MSMEs development policy by Bank Indonesia.

Development of MSMEs has various points of view such as (Afkar, et al., 2020) explaining that the development of MSMEs can be seen from an increase in income, business scale, and business diversification. Of course, it needs support from the ability of MSMEs Factors in managing their administration to find out the income from their business (Afkar et al., 2018). However, there are still many problems 
when these MSMEs will develop, especially the lack of capital both in number and source, lack of managerial ability and skills to operate in organizing and limited marketing. In addition, there is also unfair competition and economic pressure, which results in a narrow and limited scope of business (Suci et al., 2017). Coupled with the covid-19 pandemic which further reduces business opportunities (Rohmah, 2020) which is a challenge to jointly improve the national economy (Kholidah \& Hakim, 2018) in difficult times at this time because during the covid-19 pandemic MSMEs were in a state of crisis (Tambunan, 2020).

The role of Islamic financial institutions in supporting Bank Indonesia policies for the development of MSMEs can be seen from the distribution of funds to customers through investment financing and working capital financing. For Islamic banks, channeling funds to customers uses a profit-sharing system for the types of productive businesses in the real sector. The profit-sharing system in Islamic financial institutions is usually carried out by providing financing for business investment schemes which can be done by means of mudarabah contract and musharakah contract. Mudarabah contract is a business collaboration between the fund owner (shahibul maal) and the fund manager (mudarib) where the financing is provided entirely by the owner of the fund (shahibul maal) with the profit sharing according to the agreement and the financial loss is borne by the owner of the fund (shahibul maal). Meanwhile, musharakah is a business cooperation contract in which each party contributes to the paid-in capital provided that the profit sharing is in accordance with the agreement and the losses are divided according to the portion of the paid-up capital (Afkar, 2015). The problem is when customers cannot repay their loans, which causes the emergence of Non-Performing Financing (NPF), which can cause a decrease in the level of profitability, as predicted in 2021 , the last quarter of Islamic banks suffered losses (Afkar \& Fauziyah, 2021).

Table 1. Islamic Banks Financing (Billion IDR)

\begin{tabular}{lrrrrr}
\hline Type of Financing & \multicolumn{1}{c}{2016} & \multicolumn{1}{c}{2017} & \multicolumn{1}{c}{2018} & \multicolumn{1}{c}{2019} & 2020 \\
\hline 1. Working Capital & 68.420 & 72.188 & 72.425 & 79.986 & 80.965 \\
\hline MSMEs & 28.458 & 28.973 & 27.392 & 32.326 & 35.579 \\
\hline NPF & 1.751 & 1.826 & 1.429 & 1.339 & 1.707 \\
\hline 2. Investment & 45.768 & 47.427 & 48.773 & 53.207 & 56.203 \\
\hline MSMEs & 15.589 & 16.004 & 17.427 & 19.524 & 21.739 \\
\hline NPF & 1.541 & 900 & 744 & 821 & 879 \\
\hline 3. Profit Sharing & 61.629 & 67.049 & 74.122 & 89.995 & 96.376 \\
\hline Mudharabah & 7.577 & 6.584 & 5.477 & 5.413 & 4.098 \\
\hline NPF & 197 & 207 & 81 & 86 & 107 \\
\hline Musharakah & 54.052 & 60.465 & 68.644 & 84.582 & 74.122 \\
\hline NPF & 2.376 & 3.335 & 2.593 & 2.774 & 74.122 \\
\hline
\end{tabular}

Sources: Bank Indonesia

The concept of profit sharing has actually been proposed to overcome the low cost of sharing by implementing new rules and an incentive system (Ascarya \& Yumanita, 2007), but the concept has not yet provided the expected results because the profit sharing system has consequences that must be considered. For Islamic financial institutions, namely the risk of uncertainty of results
(Ernawati, 2016), although in fact the principle of profit sharing distribution has been regulated in the National Sharia Council-Indonesian Ulema Council at fatwa No. 15 which explains revenue sharing and profit sharing (Dewan Syariah Nasional- Majelis Ulama Indonesia, 2000a) and of course there are risk sharing in accordance with the agreement of the parties involved in the 
transaction. This risk sometimes has a negative impact on the emergence of problematic financing in Islamic financial institutions, especially when the difficulty of the Covid-19 pandemic adds to new problems in the real sector and the financial sector (Yunita, 2021).

The mixed theory point of view provides a view of the problems that occur between MSMEs actors and Islamic financial institutions, in this case the Islamic banks regarding profitsharing system transactions. Basically, in every business investment transaction with a profit-sharing scheme, there is a mixture of assets and finance carried out by the parties involved which is accompanied by a certain agreement as a form of compliance with sharia principles so that fraud does not occur (Najib \& Rini, 2016). When there is a party that does not carry out the agreement in the contract properly, what happens is a problem that can be intentionally caused by the customer not to pay his loans so that the bank experiences losses. Actually this problem has been regulated in (Dewan Syariah Nasional- Majelis Ulama Indonesia, 2000b) regarding sanctions for customers who delay payment, there should be no more bad credit problems if they comply with sharia principles, but in reality this is not completely the case (Biyantoro, 2019).

The problem experienced by Islamic banks in profit-sharing financing is the occurrence of non-performing financing, while the problem faced by MSMEs is the uncertainty in managing the business from the income they earn, which results in being unable to repay the loan. In the concept of sharing the risk of financial loss is borne by Islamic banks, so it needs special attention when bad credit occurs. Research (Tubastuvi, 2018) explains that the profit-sharing system has an effect on easy access to finance, it should be easy to access finance to develop MSMEs, but it turns out that the use of financing is not able to develop MSMEs (Sakur, 2011). The results of this study are also supported by (Afkar, 2017) which explains that profit-sharing financing with the mudaraba scheme is not able to have a positive impact on Islamic banks because there are still financing problems (Afkar, 2018).

Previous research still see from the side of Islamic banks as providers of Islamic financing products as explained (Afkar, et al., 2020) that the role of Islamic banks in developing MSMEs through financing is simultaneously there is a risk of loss caused by nonperforming financing other than That is the condition of the Covid-19 pandemic that has not ended, followed by smaller business opportunities from MSME actors (Tambunan, 2020). In addition, it is also explained that capital adequacy and profitability affect non-performing financing (Priyadi et al., 2021) and also the development of MSMEs from Islamic banks can be seen from the mudarabah and musharakah schemes (Huda, 2012) it shows that it is still seen from the bank sharia side only.

Meanwhile, the behavior of delaying payment of obligations from customers, as well as problems for the development of other MSMEs such as business continuity are things that must be considered in order to contribute to the national economy by using the triple bottom up (people, profit, planet) concept where this concept requires a balance to obtain benefits while at the same time prospering the community and the surrounding environment (Istikhoroh et al., 2018). Meanwhile, using mudarabah and musharakah contracts requires high morals and ethics in payment performance, according to MSMEs actors in Malaysia, the experience of microfinance and business operations has no significant effect on mudarabah and musharakah instruments (Islam \& Ahmad, 2020). It is a consideration in this research with the aim of finding the design of MSMEs development through a profit-sharing scheme that is seen from the perception of MSMEs actors. 


\section{METHODS}

Quantitative research approach is used to determine the design of MSMEs development using a profit-sharing scheme from the perceptions of MSMEs actors through the distribution principle for the results. The total population of MSMEs at the time this research was conducted was $6,825,931$ according to data from the Department of Cooperatives and SMEs. Random sampling is used as a sampling technique, then respondents are determined proportionally according to the number of MSMEs in East Java as many as 220 respondents' observations (Ferdinand, 2006).

In this research, there are 2 (two) exogenous variables, namely Mudarabah Financing $\left(X_{1}\right)$ with the indicator Mudarabah Mutlaqah $\left(\mathrm{X}_{1.1}\right)$ which is the capital given to MSMEs with fund management carried out absolutely by the mudarib (manager of fund) while the owner of the funds does not interfere in business management. Mudarabah Muqayyadah $\left(X_{1.2}\right)$ is the capital given to MSMEs with the management of funds for the business given control or restrictions by the owner of the funds (Shahibul maal), Mudarabah Mustharakah $\left(\mathrm{X}_{1.3}\right)$ is the capital given to MSMEs with the initial funding being fully Islamic Banks then after running, the fund manager provides additional capital, and Musharakah Financing $\left(\mathrm{X}_{2}\right)$ with the indicator Permanent Musharakah $\left(\mathrm{X}_{2.1}\right)$ is a business collaboration where each partner transfers capital to each other, profit sharing is based on an agreement while the risk of loss is based on the portion of the capital that is paid, and Musharakah Mutanaqisah $\left(\mathrm{X}_{2.2}\right)$ is a business cooperation which at the end of the contract period, ownership of the business can be transferred to other partners with a return on capital to other partners. The Intervening variable, namely the Principle of Profit-Sharing Distribution ( $Z$ ), is a profit sharing system for the business carried out by the business manager. Indicators The principle of profit sharing uses on the basis of revenue sharing $\left(Z_{1}\right)$, profit sharing $\left(Z_{2}\right)$, risk sharing $\left(Z_{3}\right)$. Endogenous variable, namely the Development of MSMEs ( $Y$ ), is the development of MSMEs in accordance with the scheme and access to capital in Islamic financial institutions. It Indicator uses Increased Income $\left(Y_{1}\right)$, Business Scale $\left(Y_{2}\right)$, Business Diversification $\left(Y_{3}\right)$.

The data analysis technique used Warp PLS (Partial Least Square) with intervening variable modeling. The outer model feasibility test is to determine the validity and reliability of research instruments with discriminant validity and convergent validity. Meanwhile, the Inner Model Test is used to test the path coefficient on exogenous to endogenous variables, in addition to testing the path coefficient of exogenous to endogenous variables through intervening variables, so that the ideal MSMEs development design can be found.

\section{RESULTS AND DISCUSSION}

\section{Goodness of Fit Inner Model}

Table 2. Direct Effect

\begin{tabular}{|c|c|c|c|c|c|}
\hline \multirow[b]{2}{*}{ No } & \multicolumn{2}{|c|}{ Variable } & \multirow[b]{2}{*}{ Path Coefficient } & \multirow[b]{2}{*}{$p$-value } & \multirow[b]{2}{*}{ Significant } \\
\hline & Exogenous & Endogenous & & & \\
\hline 1 & $\mathrm{X}_{1}$ & Z & 0.17 & $p<0.01$ & Highly signifincant \\
\hline 2 & $\mathrm{X}_{2}$ & Z & 0.91 & $p<0.01$ & Highly signifincant \\
\hline 3 & $\mathrm{X}_{1}$ & $Y$ & 0.31 & $p<0.01$ & Highly signifincant \\
\hline 4 & $\mathrm{X}_{2}$ & $Y$ & 0.55 & $p<0.01$ & Highly signifincant \\
\hline 5 & Z & $Y$ & -0.13 & $\mathrm{p}=0.02$ & Highly signifincant \\
\hline
\end{tabular}

Table 2 shows the calculation of the influence of the variable Mudarabah
Financing $\left(X_{1}\right)$ on the Principle of ProfitSharing Distribution (Z). In this calculation, the path coefficient value is 
0.17 with a significance level of $<0.005$ or a $p$-value $<0.01$. It explains that the Mudarabah Financing $\left(X_{1}\right)$ has a significant effect on the Principle of Profit-Sharing Distribution (Z). The calculation of the influence of the variable Musharakah Financing $\left(X_{2}\right)$ on the Principle of Profit-Sharing Distribution $(Z)$. In this calculation, the path coefficient value is 0.91 with a significance level of $<0.001$ or a $p$-value $<0.01$. It explains that the Musharakah Financing $\left(X_{2}\right)$ has a significant effect on the Principle of Profit-Sharing Distribution (Z). Table 7 also shows the calculation of the influence of the variable Mudarabah Financing $\left(X_{1}\right)$ on the Development of MSMEs $(Y)$. In this calculation, the path coefficient value is 0.55 with a significance level of $<0.001$ or a $p$-value $<0.01$. It explains that
Musharakah Financing $\left(X_{2}\right)$ has a significant effect on Development of MSMEs (Y). It shows the calculation of the influence of the variable Musharakah Financing $\left(X_{2}\right)$ on the development of MSMEs (Y2). In this calculation, the path coefficient value is 0.31 with a significance level of $<0.001$ or a $p$-value $<0.01$. It explains that the Musharakah Financing $\left(X_{2}\right)$ has a significant effect on the development of MSMEs (Y). Also the calculation of the influence of variable Principle of Profit-Sharing Distribution (Z) on development of MSMEs (Y). In this calculation, the path coefficient value is -0.13 with a significance level of $<0.002$ or $p$-value $<0.001$. This calculation explains that the hypothesis of the Principle of Profit-Sharing Distribution $(Z)$ has a significant effect on the development of MSMEs $(Y)$.

Table 3. Indirect Effect

\begin{tabular}{cccccc}
\hline \multirow{2}{*}{ No } & \multicolumn{2}{c}{ Variable } & \multirow{2}{*}{ Path Coefficient } & p-value & Significant \\
\cline { 2 - 3 } & Intervening & Endogenous & & & \\
\hline 1 & $\mathrm{X} 1{ }^{*} \mathrm{Z}$ & $\mathrm{Y}$ & -0.023 & 0.018 & Highly signifincant \\
2 & $\mathrm{X} 2^{*} \mathrm{Z}$ & $\mathrm{Y}$ & -0.134 & 0.002 & Highly signifincant \\
\hline
\end{tabular}

Table 3 shows the results of the calculation of the indirect effect of the variable mudarabah Financing $\left(X_{1}\right)$ on the Development of MSMEs ( $Y$ ) through the Principle of Profit-Sharing Distribution $(Z)$ shows the path coefficient of -0.023 (table 8) with a significance value of 0.018 so that it can be said to have an indirect effect on the level of significantly high. These results indicate that there is an indirect effect of mudarabah financing $\left(\mathrm{X}_{1}\right)$ on the development of MSMEs $(Y)$ through the Principle of Profit-Sharing Distribution (Z), so it can be said that the Principle of Profit Sharing Distribution $(Z)$ is a mediation in the development of MSMEs
(Y). The results of the calculation of the indirect effect of the Musharakah Financing variable $\left(X_{2}\right)$ on the Development of MSMEs $(Y)$ through the Principle of Profit-Sharing Distribution (Z) shows a path coefficient of -0.134 (table 4) with a significance value of 0.002 so that it can be said to have an indirect effect on the level of significantly high. These results indicate that there is an indirect effect of Musharakah Financing $\left(X_{2}\right)$ on the development of MSMEs $(Y)$ through the Principle of Profit-Sharing Distribution (Z), so it can be said that the Principle of Profit Sharing Distribution $(Z)$ is a mediation in the development of MSMEs (Y).

Table 4. Absolute Contributions

\begin{tabular}{cccc}
\hline Absolute Contributions & Total Effect & Squared & Contribution (\%) \\
\hline$X_{1}$ to $Z$ & 0,170 & 0,02820 & 2.80 \\
$X_{2}$ to $Z$ & 0.910 & 0.82800 & 82,80 \\
$X_{1}$ to $Y$ & 0.292 & 0.08500 & 8.50 \\
$X_{2}$ to $Y$ & 0.412 & 0.17000 & 1.70 \\
$Z$ to $Y$ & -0.133 & 0.01800 & 1.80 \\
$X_{1}{ }^{*}$ to $Y$ & -0.023 & 0.00059 & 0.05 \\
$X_{2}{ }^{*}$ to $Y$ & -0.134 & 0.01795 & 1.79 \\
\hline
\end{tabular}


Results of the calculation of the absolute contribution of each variable show that the variable of musharakah financing $\left(X_{2}\right)$ has a total contribution to the principle of profit-sharing distribution (Z) which is greater than the other variables, which is $82.80 \%$, besides that the contribution of musharaka financing $\left(\mathrm{X}_{2}\right)$ is mediated by the principle of profit sharing distribution $(Z)$ is also dominant at $1.79 \%$ in the development of MSMEs (Y).

Table 5. General Model Elements

\begin{tabular}{clccc}
\hline No & Model Fit and Quality Indices & Fit Criteria & Result & Model \\
\hline 1 & Average Path Coefficient (APC) & $\mathrm{p}<0.05$ & $0.435, \mathrm{p}<0.001$ & Good \\
2 & Average R-squared (ARS) & $\mathrm{p}<0.05$ & $0.837, \mathrm{p}<0.001$ & Good \\
3 & Average Adjusted R-squared & $\mathrm{p}<0.05$ & $0.835, \mathrm{p}<0.001$ & Good \\
4 & Average block VIF (AVIF) & Acceptable if $\leq 5$, ideally $\leq$ & 4.346 & Accepted \\
5 & Average full Colliniearity VIF (AFVIF) & Acceptable if $\leq 5$, ideally $\leq$ & 4.30 & Accepted \\
\hline
\end{tabular}

Table 5 is the general model elements that are used as indicators of the feasibility or goodness of fit of the inner model. The analysis results show the Average Path Coefficient (APC) or the average path coefficient of 0.435 with a significance level of $p$-value $<0.001$, meaning that the coefficient on each path has a contribution from exogenous variables (Mudarabah financing and Musharakah financing) to endogenous variables (Development of MSMEs) as well as the mediation model (Principle of Profit-Sharing Distribution) on endogenous variables (Development of MSMEs).

The Average R-squared (ARS) 0.837 with a value isp-value of $p<0.001$ and Average Adjusted $R$-squared of $0.688 p$-value $\mathrm{p}<0.001$, meaning that it shows a significant $83.70 \%$ influence on exogenous variables (Mudaraba
Financing and Musharakah Financing) towards endogenous variables (Development of MSMEs) through mediation (Principle of Profit-Sharing Distribution). While the remaining $31.20 \%$ is influenced by other variables not used in this study.

The average block VIF (AVIF) value of $2,256<4,346<5,000$ is included in the accepted category and the Average Full Colliniearity VIF (AFVIF) value of $3,300<4,149<5,000$ is included in the accepted condition. This means that the results of this analysis indicate that each variable in this study is free from multicollinearity. Freedom from multicollinearity indicates that each variable is not related to each other or does not have a significant correlation so that each variable used in this study is independent or independent as shows in Figure 1.

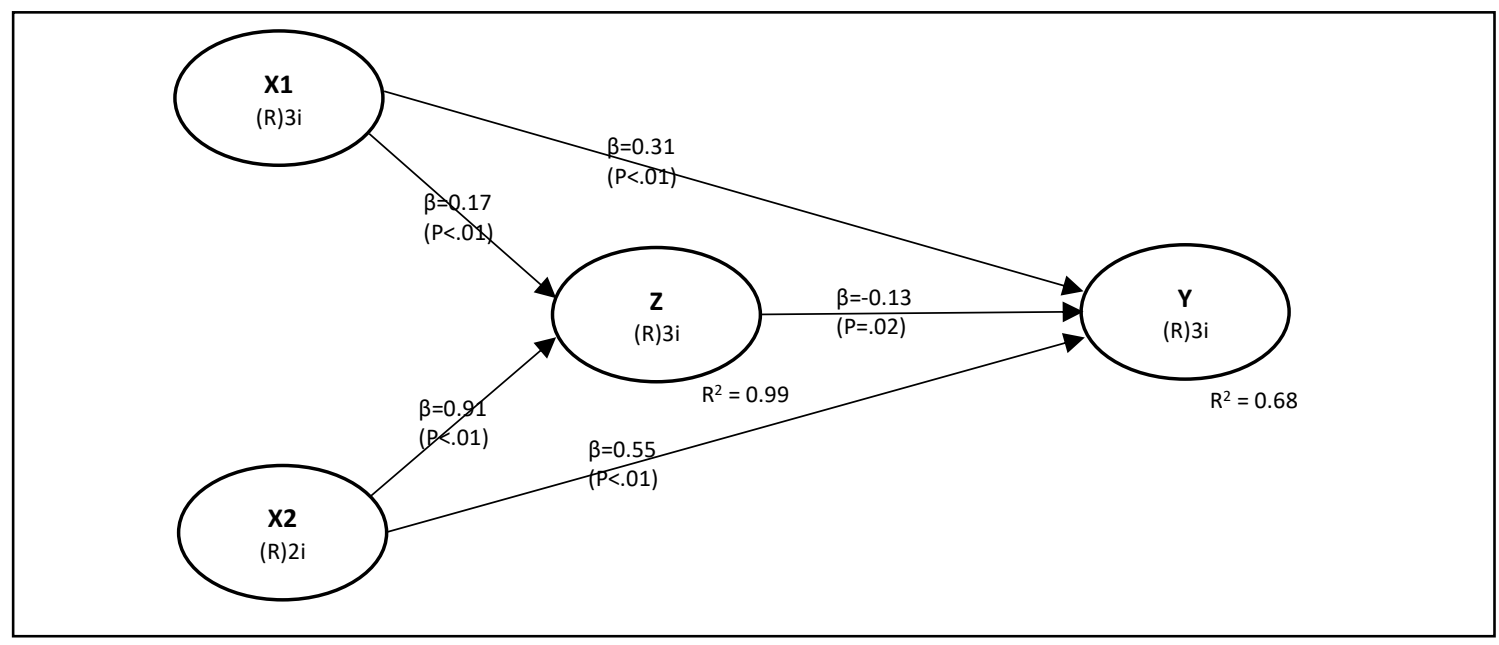

Figure 1. Design of Development of MSMEs in East Java 


\section{Contribution of the Mudaraba Financing, Musharaka Financing, and the Principle of Profit-Sharing Distribution in the Development of MSMEs}

Research results shows that the mudarabah financing scheme has an effect on the development of MSMEs, it shows that the mudaraba contract scheme carried out by means of mudarabah mutlaqah, mudarabah muqayyadah, and mudarabah mustyarakah contributes to the development of MSMEs as a whole. The results of this study support the previous research conducted (Afkar et al., 2019) where the development of MSMEs according to the perspective of MSMEs actors can be carried out by designing a mudarabah capital scheme with a mudarabah mutlaqah design, meaning between MSMEs actors and business capital providers (in this case Islamic Bank) can develop MSMEs such as increasing income, enlarging business scale, and business diversification when Islamic banks provide opportunities for MSMEs actors to fully manage their business while still adhering to sharia principles. Adherence to Islamic sharia principles is also supported by (Susilo \& Anam, 2018) which explains that compliance with Islamic sharia principles is one of the requirements that must be carried out for transactions based on natural uncertainty contracts because there is a risk of uncertainty in business investment.

Further research conducted with the mudarabah scheme (Afkar, et al., 2020) the results remain consistent that the mudaraba capital scheme indicates that it can contribute to the development of MSMEs. It means that using the mudarabah capital scheme can provide opportunities for MSMEs actors to develop their business, such as support from microfinance institutions in terms of access to finance and the need to adjust technological developments in marketing their products (Kholidah \& Hakim, 2018). However, it is different from (Sakur, 2011) which explains that the use of financing as business capital does not have a contribution to the development of MSMEs but rather a strategy in product marketing that needs to be developed. In addition (Ariani \& Utomo, 2017) also revealed that the development and competitiveness of MSMEs in Tarakan was carried out by maintaining the quality of raw materials, legality or product permits that were qualified, prices that remained competitive and improving human resources. Thus, as happened in Malaysia and Pakistan that small and medium enterprises need fundamental steps to develop and grow as businesses that contribute to the national economy (Khan \& Khalique, 2014).

Various development of MSMEs strategies show the purpose of MSMEs actors, the role of financial institutions, and the government to pay attention to the sustainability of MSMEs in contributing to the national economy. As stated (Istikhoroh et al., 2018) that to build the sustainability of small and medium enterprises can be done by strengthening triple bottom line management, namely people, planet, profit. Profit cannot be separated from every business sustainability, therefore this study provides an overview of the contribution of the musharakah financing scheme where the parties involved in the musharakah scheme are entitled to benefit according to the agreement in the contract and also share the risk of loss in accordance with the portion of paid-up capital. Even so, this musharakah financing scheme provides opportunities for MSMEs actors to have a complete business from the business that is being carried out together with business partners by conducting musharakah mutanaqisah contract, it is evident in this study that musharakah financing provides the most dominant contribution. The musharakah mutanaqisah contract scheme can be carried out by mutual agreement until the end of the contract period through the return of the total capital portion to the business partner (Nurhayati \& Wasilah, 2015). 
Principle of profit-sharing distribution in this study can be an intervening variable in the development of MSMEs in East Java. Basically, the application of the principle of profitsharing distribution takes into account the indicators of revenue sharing, profit sharing and risk sharing. It means that in addition to the sharing of profits based on an agreement, whether it is using the calculation of net or gross profits, the sharing of risks against business losses is an indicator of fairness in doing business. The loss in business with this profit sharing design is one of the risks faced in business competition for MSMEs actors (Şener et al., 2014), on the other hand it is also a risk for Islamic banks which will result in the emergence of Non Performing Financing). As long as the risk of loss is not carried out intentionally by the MSMEs actors, the distribution of the risk of loss is still in accordance with the mudarabah and musharakah contract, but if the loss is caused because the MSMEs actor as a financing customer deliberately provides reports on incorrect business activities and negligence by the MSMEs actor, then the agreement risk sharing does not apply in the design of profit sharing systems.

\section{Design of MSMEs Development}

Findings in this study are the contribution of the principle of profitsharing distribution as an intervening variable in the development of MSMEs through the mudarabah and musharakah contract schemes. The findings of this study are seen from the perspective of MSMEs Actors in looking at the products of Islamic financial institutions that provide sharia financing products with a profit-sharing system. the type of profit-sharing financing does not dominate the various types of financing available in Islamic financial institutions such as murabahah financing (Iskandar, 2016) but the profitsharing segment is for the productive sector with the aim of helping entrepreneurs who are classified as MSMEs to develop their businesses.
The point of view of developing MSMEs from sharia financial institutions as providers of funds through financing can be seen from their role in providing financing to MSMEs with mudarabah and musharakah financing schemes. Of course, it role cannot be separated from obtaining profits in the profit-sharing scheme so that it becomes one of the funds that can be used to support national economic growth through the development of MSMEs. This statement is in line with (Permata et al., 2014) which explains that mudarabah and musharakah financing is able to contribute to profits for Islamic banks. Likewise (Wibowo \& Sunarto, 2014) with the same explanation, but different from (Sari \& Anshori, 2018) which states that musharakah financing has an effect on profits while mudarabah financing has no effect, this is the same as research (Afkar, 2017) where it is explained that mudarabah financing has no effect on profits. Even so, mudarabah and musharakah financing have an effect on profits, always followed by the presence of Non Performing Financing which can weaken the ability of Islamic banks to earn profits (Afkar, et al., 2020). However, there is a different view from (Saputra, 2013) which explains that Non Performing Financing has no effect on the profitability of Islamic banks. Thus, in principle, Islamic financial institutions as owners of funds still have the right to benefit even though there is a risk of loss in the mudarabah and musharakah financing schemes.

The development of MSMEs from the perspective of MSMEs actors can be seen from the dominant contribution of musharakah financing in developing MSMEs by mediating the principle of profit sharing even though previous research was more dominated by mudarabah mutlaqah financing (Afkar et al., 2019), where MSMEs want a sharia financing scheme with way of partnership through co-financing with different portions of the capital injection. In addition, profit sharing is also in the form of mutual agreement and risk loss sharing according to the portion of paid- 
up capital, plus there is an opportunity for MSMEs actors to own this business through musharakah mutanaqisah after the contract period is over. As long as the MSMEs actors do not violate the provisions in the agreed musharakah contract, there will be no problems such as delaying payment of their loans. In addition, this musharakah scheme provides an opportunity for the parties involved to participate in managing the business being carried out so that the opportunity not to comply with sharia principles does not exist because there is joint control in running a sharia-based business which is a requirement for sharia transactions (Susilo \& Anam, 2018) as well as a form of compliance of Islamic financial institutions with Islamic sharia principles in running their business (Sepky, 2015).

The dominance of musharakah financing in its contribution to developing MSMEs illustrates that togetherness in managing business assets is very important, where each party involved transfers capital to each other and becomes a business manager. Judging from the mixed theory, it can be seen that MSMEs actors and Islamic financial institutions mix their capital (money and assets) which in the end will get compensation in the form of profits according to the agreement and sharing the risk of loss according to the portion of paid-up capital. On the other hand, when viewed from the agency theory in the profit-sharing scheme, there is a desire to mutually maintain the sustainability of each other's business so that the role of MSMEs actors as agents that manage business finances is carried out in accordance with the principles of distribution of profit sharing with revenue sharing, profit sharing, and fair risk sharing. Meanwhile, Islamic financial institutions as the owner of funds (Shahibul maal) expect fair profits with honesty in reporting business activities so that there is no information asymmetry that allows fraud (Afkar, et al., 2020). Fairness and honesty in the principle of profit-sharing distribution will have a positive impact on the development of MSMEs with mudaraba and musharaka financing as a form of business investment.

\section{ACKNOWLEDGEMENT}

Thanks to the Faculty of Economics and Business for the research permit that has been given and thanks to LPPM PGRI Adi Buana University Surabaya for contributing research funding.

\section{CONCLUSION RECOMMENDATION}

AND

Ideal design for developing MSMEs in East Java- Indonesia through profit-sharing scheme is carried out by means of MSMEs actors utilizing mudarabah financing and musharakah financing through the application principles of profit-sharing distribution, while Islamic financial institutions provide sharia financing in accordance with the wishes of MSMEs actors with fair business cooperation in distribution profit and risk sharing of business losses in accordance with Islamic sharia principles. The development of MSMEs in the form of increasing income, increasing business scale, and business diversification will be achieved if the implementation of the correct profitsharing distribution principle by paying attention to revenue sharing, profit sharing, and sharing of risk of loss contained in mudarabah and musharakah financing.

In East Java shows that Musharakah financing is the most dominant type of sharia financing in the development of MSMEs which is mediated by the principle of profitsharing distribution, thus the design of MSMEs development that is more attractive to MSMEs is by cooperating business partnerships through capital deposits and joint business management. Its means that MSMEs actors are not only users of funds from musharakah financing but also as business owners according to the portion of capital owned in the business being run, besides that there is an opportunity to own the business after the 
musharakah contract period is over with the agreement of the parties involved in the contract, of course the business is being carried out based on Islamic sharia principles.

\section{REFERENCES}

Afkar, T. (2015). Financing mechanism of islamic banking. International Journal of Social Sciences, 32(1), 1-13.

Afkar, T. (2017). Influence Analysis Of Mudharabah Financing And Qardh Financing To The Profitability Of Islamic Banking In Indonesia. AJIE - Asian Journal of Innovation and Entrepreneurship, 2(3), 340-351.

Afkar, T. (2018). Influence Analysis Of Non Performing Financing By Profit-Loss Sharing Financing Contract To The Profitability Of Islamic Commercial Bank In Indonesia. AKRUAL: Jurnal Akuntansi, 10(1), 1-14. https://doi.org/10.26740/jaj.v10n1. p1-14

Afkar, T., Chandrarin, G., \& Pirmaningsih, L. (2020). Moderation of Non Performing Financing on Natural Uncertainty Contracts To The Profitability of Islamic Commercial Bank In Indonesia. International Journal of Economics, Business and Accounting Research (IJEBAR), 4(02), 330-339. https://doi.org/10.29040/ijebar.v4i0 2.1051

Afkar, T., \& Fauziyah. (2021). Predictions And Trends Profitability For Islamic Commercial Banks In Indonesia During The Covid-19. International Journal of Economics, Business, and Accounting Research (IJEBAR), 1(1), 188196.

https://doi.org/http://dx.doi.org/10.2 9040/ijebar.v5i1.2232

Afkar, T., Utomo, S. P., Miradji, M. A., \& Hariawan, F. (2020). The Role Of Profit-Loss Sharing In Development of MSMEs. International Journal of Economics, Business and Accounting
Research (IJEBAR), 4(01), 173184.

https://doi.org/10.29040/ijebar.v4i0 1.944

Afkar, T., Utomo, S. P., Miradji, M. A., \& Hariawan, F. (2019). The Role Of Mudharabah Mutlaqah Capital Financing And The Principle Of Profit Sharing Distribution In The Development of MSMEs. International Conference of Business and Economic Adi Buana, 1-8. https://iceba.unipasby.ac.id/index. php/iceba/issue/view/1

Afkar, T., Waryanto, R. B. D., Istikhoroh, S., Subakir, Sugijanto, \& Fauziyah. (2018). Upaya Peningkatan Penghasilan UKM dengan Tertib Administrasi Keuangan di Desa Kenongo Kecamatan Tulangan Sidoarjo. AJIE - Asian Journal of Innovation and Entrepreneurship, 03(September), 351-357.

Afkar, T., Wicaksono, J. W., \& Faujiah, A. (2020). Desain Akuntansi Anti Korupsi. J-MACC: Journal of Management and Accounting, 3(1), 60-82. http://www.ejurnal.unisda.ac.id/index.php/JMACC/article/view/1859

Ariani, A., \& Utomo, M. N. (2017). Kajian Strategi Pengembangan Usaha Mikro Kecil Dan Menengah (UMKM) di Kota Tarakan. Jurnal Organisasi Dan Manajemen, 13(2), 99-118.

https://doi.org/10.33830/jom.v13i2. 55.2017

Ascarya, A., \& Yumanita, D. (2007). Mencari Solusi Rendahnya Pembiayaan Bagi Hasil di Perbankan Syariah Indonesia. Buletin Ekonomi Moneter Dan Perbankan, 8(1), 7-43. https://doi.org/10.21098/bemp.v8i1 .127

Biyantoro, A. (2019). Sharia Compliance and Islamic Corporate Governance. Trikonomika, 18(2), 69-73.

https://doi.org/10.23969/trikonomik a.v18i2.1465

Dewan Syariah Nasional- Majelis Ulama 
Indonesia. (2000a). Fatwa No: 15/DSN-MUI/IX/2000.Prinsip

Distrribusi Hasil Usaha dalam Lembaga Keuangan Syari'ah.

Dewan Syariah Nasional- Majelis Ulama Indonesia. (2000b). Fatwa No. 17/DSN-MUI/IX/2000 tentang Sanksi Atas Nasabah Mampu yang Menunda-Nunda Pembayaran.

Ernawati, E. (2016). Risk of Profit Loss Sharing Financing: the Case of Indonesia. Al-lqtishad: Journal of Islamic Economics, 8(1), 101-116. https://doi.org/10.15408/aiq.v8i1.2 511

Fauzia, I. Y. (2016). Pengembangan Softskill dalam Bisnis Syariah bagi Pelaku Usaha Mikro, Kecil dan Menengah (UMKM). ICON UCE Collaborative Creation Leads to Sustainable Change, 881-896. http://digilib.uinsby.ac.id/7444/1/IK A YUNIA Fauzia.pdf

Ferdinand, A. (2006). Metode Penelitian Manajemen. Semarang: Badan Penerbit Universitas Diponegoro. Semarang: Badan Penerbit Universitas Diponegoro.

Huda, A. N. (2012). The Development of Islamic Financing Scheme for SMEs in a Developing Country: The Indonesian Case. Procedia Social and Behavioral Sciences, 52, 179-186. https://doi.org/10.1016/j.sbspro.20 12.09.454

Iskandar, R. (2016). Kontribusi dan Pertumbuhan Pembiayaan Bank Syariah Di Indonesia Berdasarkan Jenis Akad Periode Tahun 20082013. Maqdis: Jurnal Kajian Ekonomi Islam, 1(2), 237-248. https://doi.org/http://dx.doi.org/10.1 5548/maqdis.v1i2.48

Islam, R., \& Ahmad, R. (2020). Muḍārabah and mushārakah as micro-equity finance: perception of Selangor's disadvantaged women entrepreneurs. ISRA International Journal of Islamic Finance, 12(2), 217-237.

https://doi.org/10.1108/IJIF-042018-0041

Istikhoroh, S., Afkar, T., \& Handayani, C.
M. S. (2018). Building Sustainability Strategy on Implementation of Small Business With Triple Bottom Line. International Conference on Entrepreneurship ( ICOEN ), 5(Agustus), 118-125.

Khan, M. W. J., \& Khalique, M. (2014). An Overview of Small and Medium Enterprises in Malaysia and Pakistan: Past, Present and Future Scenario. Business and Management Horizons, 2(2), 38. https://doi.org/10.5296/bmh.v2i2.5 792

Kholidah, N., \& Hakim, M. R. (2018). Peluang dan Tantangan Pengembangan Usaha Mikro Kecil Menengah (UMKM) Dari Berbagai Aspek Ekonomi. Jurnal IImiah Manajemen Dan Bisnis, 2(1), 181197.

https://doi.org/https://doi.org/10.38 043/jimb.v2i1.155

Najib, H., \& Rini. (2016). Sharia Compliance, Islamic Corporate dan Fraud Pada Bank Syariah. Akuntansi Dan Keuangan Islam, 4(2), 131-146.

Nurhayati, S., \& Wasilah. (2015). Akuntansi Syariah Di Indonesia. Jakarta : Selemba Empat.

Pakpahan, A. K. (2020). Covid-19 Dan Implikasi Bagi Usaha Mikro, Kecil, Dan Menengah. JIHI: Jurnal IImu Hubungan Internasional, 20(April), 2-6. https://doi.org/https://doi.org/10.26 593/jihi.v0i0.3870.59-64

Permata, R. I. D., Yaningwati, F., \& A, Z. Z. (2014). Analisis pengaruh pembiayaan mudharabah dan musyarakah terhadap tingkat profitabilitas ( return on equity ) ( studi pada bank umum syariah yang terdaftar di bank indonesia periode 2009-2012 ). Jurnal Administrasi Bisnis, 12(1), 1-9.

Priyadi, U., Utami, K. D. S., Muhammad, R., \& Nugraheni, P. (2021). Determinants of credit risk of Indonesian Sharīiah rural banks. ISRA International Journal of Islamic Finance. https://doi.org/10.1108/IJIF-09- 
2019-0134

Rohmah, S. N. (2020). Adakah Peluang Bisnis di Tengah Kelesuan Perekonomian Akibat Pandemi Coronavirus Covid-19? 'ADALAH; Buletin Hukum \& Keadilan, 4(1), 63-74.

https://doi.org/https://doi.org/10.15 408/adalah.v4i1.15448

Sakur. (2011). Kajian Faktor-Faktor yang Mendukung Pengembangan Usaha Mikro Kecil dan Menengah.

Spirit Publik, 7(2), 85-109. https://core.ac.uk/download/pdf/20 332749.pdf

Saputra, A. W. (2013). Pengaruh Non Performing Finance (NPF) Pembiayaan Mudharabah dan Non Performing Financing (NPF) Pembiayaan Musyarakah Terhadap Profitabilitas Perbankan Syariah (Studi Kasus pada PT. Bank Syariah Mandiri Tahun 19992013). Syariah Paper Accounting. FEB UMS, ISSN 2460-0784, 10, 111.

Sari, D. W., \& Anshori, M. Y. (2018). Pengaruh Pembiayaan Murabahah, Istishna, Mudharabah, Dan Musyarakah Terhadap Profitabilitas (Studi Pada Bank Syariah Di Indonesia Periode Maret 2015 - Agustus 2016). Accounting and Management Journal, 1(1),1-8. https://doi.org/10.33086/amj.v1i1.6 8

Şener, S., Savrul, M., \& Aydın, O. (2014). Structure of Small and Medium-Sized Enterprises in Turkey and Global Competitiveness Strategies. Procedia - Social and Behavioral Sciences, 150(10), 212-221. https://doi.org/10.1016/j.sbspro.20 14.09.119

Sepky, M. (2015). Tingkat Kepatuhan Syariah di Lembaga Keuangan Syariah. Jurnal Akuntansi Dan Keuangan Islam, 3(1), 57-68. http://jurnal.sebi.ac.id/index.php/ja $\mathrm{ki} / \mathrm{article} / \mathrm{view} / 46$

Suci, Y. R., Tinggi, S., \& Ekonomi, I. (2017). Perkembangan UMKM (Usaha Mikro Kecil Menengah) di
Indonesia. Jurnal IImiah Fakultasi Ekonomi, 6(1), 51-58. https://ejournal.upp.ac.id/index.php/Cano/a rticle/view/1239

Susilo, E., \& Anam, A. K. (2018). Sharia Complience Akad Berbasis Natural Uncertainty Contract (Nuc) Lembaga Keuangan Mikro Syariah Di Kabupaten Jepara. Al-Uqud: Journal of Islamic Economics, 2(1), 20-37. https://doi.org/10.26740/aluqud.v2n1.p20-37

Tambunan, T. (2019). Recent evidence of the development of micro, small and medium enterprises in Indonesia. Journal of Global Entrepreneurship Research, 9(1). https://doi.org/10.1186/s40497018-0140-4

Tambunan, T. (2020). MSMEs in times of crisis. evidence from Indonesia. Journal of Developing Economies, 5(2), 91. https://doi.org/10.20473/jde.v5i2.2 0848

Tubastuvi, N. (2018). The Role of Profitand-Loss Sharing Contracts in Strenghtening Financing Access of Small Medium Enterprise's (SME's): The Case of Indonesia. Advanced Science Letters, 24(1), 129-132.

https://doi.org/10.1166/asl.2018.11 938

Wibowo, A., \& Sunarto. (2014). Pengaruh Pembiayaan Mudharabah Dan Musyarakah Terhadap Profitabilitas Perbankan Syariah (Studi Kasus Pada Bank Pembiayaan Rakyat Syariah Daerah Istimewa Yogyakarta Yang Terdaftar Di Bank Indonesia Periode 2012-2014). Seminar Nasional Dan The 3rd Call for Syariah Paper, 115-124.

Yunita, P. (2021). How Has The Covid19 Pandemic Affected The Real And Monetary Sectors In Indonesia? Journal of Islamic Monetary Economics and Finance, 7(1), 137-166. https://doi.org/https://doi.org/10.21 098/jimf.v7i0.1361 